\title{
BISAKAH TRANSPLANTASI KARANG PERBAIKI EKOSISTEM TERUMBU KARANG ?
}

\author{
Beginer Subhan ${ }^{1 *}$ Hawis Madduppa ${ }^{2}$, Dondy Arafat ${ }^{1}$ Dedi Soedharma ${ }^{1}$ \\ ${ }^{1}$ Laboratorium Selam Ilmiah, Departemen Ilmu dan Teknologi Kelautan \\ Fakultas Perikanan dan Ilmu Kelautan, Institut Pertanian Bogor \\ ${ }^{2}$ Laboratorium Biosistematika dan Biodiversitas Kelautan, Departemen Ilmu dan Teknologi Kelautan \\ Fakultas Perikanan dan Ilmu Kelautan, Institut Pertanian Bogor \\ *E-mail : beginer.subhan@gmail.com
}

\begin{abstract}
RINGKASAN
Transplantasi karang merupakan teknik perbanyakan koloni karang dengan memanfaatkan reproduksi aseksual karang secara fagmentasi. Berbagai kalangan dapat terlibat dalam mengusahakan dan melakukan rehabilitasi karang dengan metode ini. Namun saat ini metode yang digunakan masih ada yang mengadopsi metode untuk perdagangan karang hias bukan untuk rehabilitasi. Metode dengan beton dan pengontrolan terhadap alga salah satu kunci keberhasilan dalam transplantasi karang. Pencarian bibit-bibit karang yang unggul yang kuat terhadap alga dan penyakit menjadi solusi penting dalam peningkatan keberhasilan transplantasi karang.
\end{abstract}

Kata kunci: transplantasi karang, metode beton, penyakit karang, alga

\section{PERNYATAAN KUNCI}

- Transplantasi karang merupakan teknik perbanyakan koloni karang dengan memanfaatkan reproduksi aseksual karang secara fagmentasi. Beberapa ahli sering juga menggunakan istilah propagasi sebagai kata lain untuk transplantasi karang.

- Metode transplantasi merupakan cara sederhana untuk perbaiki terumbu karang. Berbagai kalangan dapat terlibat dalam mengusahakan dan melakukan rehabilitasi karang dengan metode ini. Namun saat ini metode yang digunakan masih ada yang mengadopsi metode untuk perdagangan karang hias bukan untuk rehabilitasi.

- Setiap lokasi terumbu karang yang mengalami kerusakan memiliki keunikan tersendiri. Pada umunya pertimbangan pemilihan lokasi hanya berdasarkan kondisi fisik dan kimia perairan.

- Setiap tahap dalam pelaksanaan transplantasi karang merupakan faktor kunci dalam keberhasilan transplantasi karang. Tahaptahap transplantasi pemilihan lokasi, pembuatan substrat, pemilihan bibit, penanaman karang dan monitoring.

\section{REKOMENDASI KEBIJAKAN}

- Transplantasi karang merupakan kegiatan jangka panjang sehingga tidak bisa berbasis proyek. Sistem program merupakan salah satu solusi untuk meningkatkan keberhasilan 
tranplantasi karang dalam rangka rehabilitasi terumbu karang.

- Selain informasi sifat fisika dan kimia perairan, informasi mendetail tentang faktor biologi di lokasi transplantasi sangat dibutuhkan. Informasi tentang kompetitor dan predator serta penyakit karang perlu diperhatikan dengan seksama.

- Informasi tentang metode transplantasi untuk rehabilitasi kepada masyarakat umum dan penggiat rehabilitasi terumbu karang perlu disebarluaskan. Media sosial dan media informasi lainnya seperti buku dapat digunakan untuk menyebarkan informasi tersebut.

\section{PENDAHULUAN}

Terumbu karang di dunia dalam kondisi terancam oleh aktifitas manusia melalui polusi dan perubahan habitat (Burke et al. 2011). Ancaman terhadap terumbu karang di Indonesia antara lain disebabkan oleh penangkapan ikan yang tidak ramah lingkungan, pencemaran dan kerusakan yang berasal dari laut, pembangunan pesisir, dan pencemaran yang berasal dari daerah aliran sungai.

Banyak upaya yang dilakukan manusia untuk mengatasi atau memperbaiki ekosistem terumbu karang yang telah rusak. Secara umum upaya yang dilakukan adalah manajemen misalnya pembentukan kawasan konservasi perairan atau dengan teknologi rehabilitasi seperti terumbu buatan dan transplantasi karang. Tujuan utama transplantasi karang adalah untuk memperbaiki kualitas terumbu karang seperti meningkatnya tutupan karang hidup, keanekaragaman hayati dan keunikan topografi karang (Soedharma dan Arafat, 2006).

Penelitian transplantasi karang di Indonesia antara lain di Kepulauan Seribu (Subhan et al., 2008), Tanjung Lesung Banten (Zamani et al), Kepulauan Spermonde (haris 2012), dan beberapa dearah lainnya. Jenis-jenis karang yang banyak ditransplantasi antara lain Acropora (Haris 2012: Zamani et al, 2009; Madduppa et al., 2007), Euphyllia sp, Plerogyra sinuosa, Cynarina lacrymalis (Subhan et al., 2008), Hynopora sp, Pocillopora dan Sylopora (Johan, 2012).

Metode transplantasi di Indonesia saat ini berbagai macam-macam (Gambar 1). Beberapa metode yang sudah digunakan adalah metode rak jaring dan substrat (Subhan et al., 2008), beton (Johan, 2012), jaring dan pecahan (Fadli, 2008), substrat alami (Haris 2012 ) dan dimodifikasi menggunakan biorock karang (Zamani et al., 2009; Madduppa et al., 2007). Setiap metode memiliki kelebihan dan kekurangan dan tidak

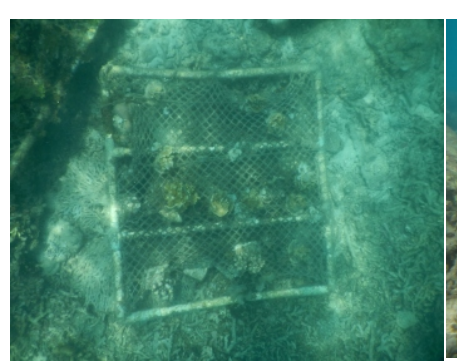

(a)

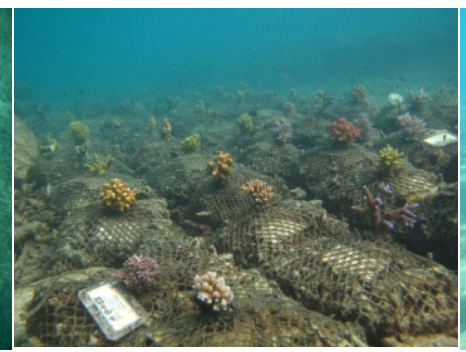

(b)

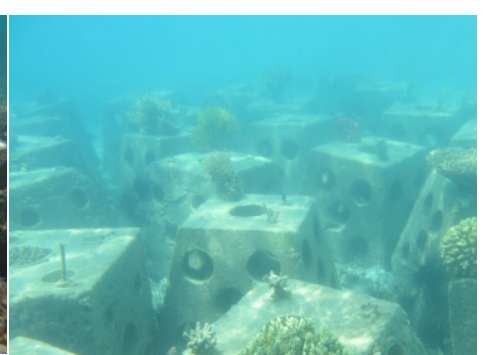

(c)

Gambar 1. Metode transplantasi karang (a) rak, jaring dan substrat, (b) jaring dan pecahan karang (c) beton (Foto: Beginer Subhan) 
semua baik untuk kegiatan rehabilitasi.

Metode-metode transplantasi terus berkembang sesuai dengan kemajuan teknologi dan pemahaman para pengguna. Metode yang mudah dan praktis merupakan metode yang paling banyak digunakan. Namun tidak semua metode praktis dan sederhana dapat menghasilkan hasil yang seperti diharapkan. Tulisan ini bertujuan untuk memberikan wawasan tentang bagaimana pelaksanaan metode dan pertimbangan dalam kegiatan transplantasi yang dapat memberikan hasil yang optimal.

\section{KONDISI TERKINI}

\section{Transplantasi karang di Indonesia}

Sejatinya pengembangan transplantasi karang di Indonesia dikembangkan untuk kegiatan perdagangan karang hias. Soedharma, 2012 mencatat bahwa pada tahun 1996 Institut Pertanian Bogor (IPB) bersama Asosiasi Koral Kerang dan Ikan Hias Indonesia (AKKI), WWF, TNI-AL dan Pusat Penelitian Oseanologi Lembaga Ilmu Pengetahuan Indonesia (P2OLIPI) menjadi pionir dalam pengembangan metode transplantasi.

Transplantasi dengan menggunakan rak, jaring dan substrat merupakan metode yang awal dan memberikan hasil yang memuaskan. Penelitian dan pengembangan dengan metode ini dilakukan sampai tahun 2004 di Kepulauan Seribu. Selanjutnya metode ini digunakan untuk kegiatan rehabilitasi karang di berbagai lokasi di Indonesia. Saat ini hampir seluruh daerah pesisir yang memiliki ekosistem terumbu karang menggunakan transplantasi karang sebagai usaha perbaikan ekosistem terumbu karang.

\section{Faktor biologi kurang ditelaah}

Parameter fisika kimia perairan menjadi kajian wajib pada saat memulai kegiatan perbaikan kondisi terumbu karang. Memang benar jika kedua parameter tersebut menunjukkan kondisi yang tidak cocok untuk pertumbuhan karang maka keberhasilan akan rendah.

Saat ini banyak kajian awal berhenti hanya sampai kondisi fisik dan kimia saja. Belum banyak faktor biologi sebagai pertimbangan lebih lanjut dalam menentukan lokasi yang menjadi prioritas transplantasi karang. Faktor biologi yang kurang menjadi perhatian adalah kompetitor.

Siapakah kompetitor karang dalam kegiatan transplantasi karang? jawabannya adalah makro alga. Daerah-daerah yang sudah dikuasai oleh makro alga biasanya sangat sulit untuk direhabilitasi. Sebagai contoh, pengalaman kegiatan transplantasi karang selama lebih 5 tahun alga menjadi penyebab utama kematian fragmen karang. Kondisi nutrien di perairan yang tinggi menjadi pemicu tumbuhnya makro alga.

Faktor biologi selanjutnya adalah penyakit karang. Beberapa penelitian mencatat bahwa sudah banyak penyakit karang yang ditemukan di Indonesia (Subhan et al 2011a; Subhan et al 2011b; Johan et al 2012). Beberapa daerah transplantasi karang mengalami penurunan tutupan karang akibat penyakit karang. Hal sempat tercatat adalah ditemukannya penyakit karang Black Band Diseases ditransplantasi karang di Pulau Serangan Bali (Gambar 2).

Penyakit karang timbul oleh berbagai faktor utama yaitu pemanasan global. Namun beberapa faktor lain perlu dipertimbangkan adalah masukan 


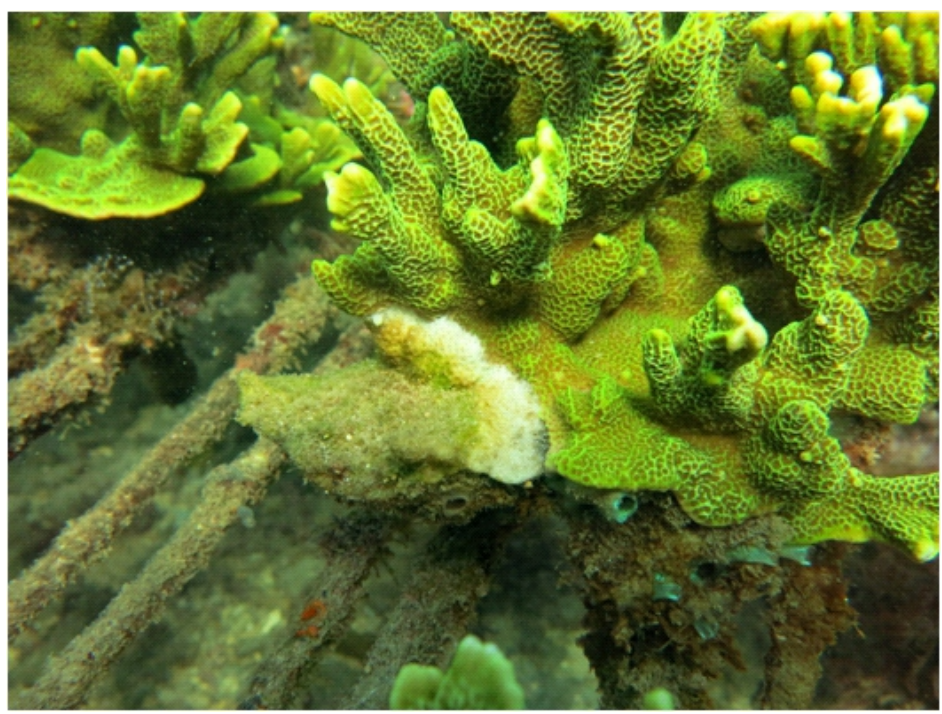

Gambar 2. Penyakit karang black band diseases ditransplantasi karang di Pulau Serangan Bali (foto: Beginer Subhan)

nutrien, sedimentasi dan run off dari daratan (Kuta and Richardson, 1996).

\section{Masih Terjebak Metode Lama}

Seiring dengan perjalanan waktu, metode rak, jaring dan substrat ini memperlihatkan kelemahan antara lain, daya tahan jaring ternyata kurang bertahan lama. Jaring mengalami putus dan sobek sering terjadi. Hal tersebut mengakibatkan karang-karang yang sudah berukuran besar terlepas dari jaring.

Metode rak, jaring dan substrat merupakan metode yang digunakan untuk budidaya karang hias. Tujuan mengunakan jaring adalah untuk memudahkan operasional dalam transplantasi. Misalnya dalam kegiatan pemanenan, penggantian karang yang mati dan pembersihan.

Namun sayang, saat ini masih banyak penggiat transplantasi karang untuk rehabilitasi karang masih menggunakan metode rak, jaring dan substrat. Pengalaman jangka panjang menunjukkan metode selain jaring, rak yang biasanya tebuat dari besi atau paralon atau kayu tidak kuat menahan beban akibat semakin besarnya koloni karang.

Sebagai pengganti rak, jaring dan substrat, konstruksi yang terbuat dari bahan beton dapat menjadi solusi. Kelebihan dari beton adalah memiliki daya tahan yang lama dan dapat membentuk formasi yang stabil. Stabilitas daerah penempelan membuat karang dapat menempel dan tumbuh dengan baik. Selain itu, beton dapat menjadi media untuk penempelan larva karang. Seperti penelitian Aziz et al (2011) menemukan bahwa banyak terjadi penempelan karang secara alami pada terumbu buatan yang terbuat dari beton.

\section{ANALISIS DAN ALTERNATIF SOLUSI}

Langkah-langkah untuk meningkatkan keberhasilan transplantasi karang dalam memperbaiki ekosistem terumbu karang dimulai 
dari: (1) Penentuan dan penelaahan lokasi terumbu karang harus memperhatian faktor fisika, kimia dan biologi. Alga dan penyakit karang merupakan faktor yang perlu diperhatikan. Pilihlah lokasi yang minim terdapat makro alga sebagai prioritas untuk rehabilitasi. (2) Alga dan penyakit juga bisa masuk ketika proses penyiapan bibit untuk transplantasi. Seleksi terhadap bibit merupakan faktor penting untuk keberhasilan. Pilihlah bibit karang yang tidak ditumbuhi alga dan sehat dari penyakit. Ciri-ciri karang yang sehat salah satunya memiliki warna yang cerah dan tegas. Perlu disiapkan bibit-bibit unggul untuk transplantasi karang. Pemerintah dan peneliti bisa menjadi aktor utama dalam penyiapan bibit-bibit ini. Bagaimana jika terdapat alga dan penyakit? Solusinya adalah perawatan intensif dan pembersihan penyakit dan alga. Monitoring dan perawatan berkala merupakan jalan terbaik untuk menghadapi alga dan penyakit. Semakin banyak alga kegiatan pembersihan dan perawatan harus dilakakukan semakin sering. Jika ditemukan penyakit karang maka karang yang terkena penyakit sebaiknya segera dimusnahkan dan diganti dengan fragmen lain. Berdasarkan pengalaman sangat jarang karang yang terkena penyakit dapat pulih kembali. (3) Pemilihan metode konkret beton merupakan salusi alternatif untuk menggantikan metode rak, jaring dan substrat. Sebenarnya di beberapa lokasi di Indonesia sudah menggunakan metode ini namun belum tersosialisasi dengan baik. Selain itu, memang metode ini relatif lebih sulit dan butuh operasional yang cukup banyak. Namun harus berhati-hati jika menggunakan beton harus benarbenar kuat agar tidak luruh atau rusak digerus air laut. Dengan langkah-langkah tersebut diharapkan tranplantasi karang dapat memberikan hasil yang maksimal dalam memperbaiki kondisi terumbu karang Indonesia.

\section{REFERENSI}

Azis, A.M., Kamal, M.M., Zamani, N.P., Subhan, B., 2011. Coral Settelment on Concrate Artificial Reef in Pramuka Island waters, Kepulauan Seribu, Jakarta and Management Option. Jurnal of Indonesian Coral Reefs 1 (1) 2011:pp55-64.

Burke, L., Reytar, K., Spalding, M., Perry, A. 2011. Reefs at Risk Revisited. World Resources Institute (WRI), Washington DC.

Fadli, N. 2008. Tingkat Kelangsungan Hidup Fragmen Karang Acropora formosa yang ditransplantasikan pada media buatan yang terbuat dari pecahan karang (Rubble). Berita Biologi 9(3) 2008: pp 265-273

Johan, O. 2012, The Survival od Transplanted Coral on Pyramid-shape Fish Shelter on the Coastal Water of Kelapa and Harapan Islands, Kepulauan Seribu Jakarta. Indonesian Aquaculture Journal 7 (1) 2012: pp79-85

Johan, O., Bengen, D.G., Zamani, N.P., Suharsono. 2012. Distribution and Abundance of Black Band Disease on Corals Montipora sp in Seribu Islands, Jakarta Journal of Indonesia Coral Reefs 1(3) 2012 pp160-170.

Kuta, K.G., Richardson, L.L. 1996 abundance and distribution of black band diseases of corals on the northern Florida Keys. Coral reef 15 1996: pp219-223.

Madduppa, H.M., Subhan, B., Bachtiar R., Ismet, M.S., Budikartini,Y., Bria, M.D. 2008. 
Prospek Terumbu Buatan Biorock dalam

Peningkatan Sumberdaya Ikan di

Kepulauan Seribu. Prosiding Munas

Terumbu Karang 2007, Program

Rehabilitasi Terumbu Karang COREMAP

II, (hlm 68-76),10-11 September 2007

Departemen Kelautan dan Perikanan.

Soedharma, D. 2012. Indonesia Maritime

Magazine Edisi16, Hal 77-78

Subhan, B., Soedharma, D., Madduppa, H., Arafat, D., Heptarina, D. 2008.

Kelangsungan Hidup dan Pertumbuhan

Karang jenis Euphyllia sp, Plerogyra sinuosa

$\mathrm{dan}$ Cynarina lacrymalis yang ditransplantasikan di Pulau Pari, Kepulauan

Seribu, Jakarta. Prosiding Seminar

Nasional Penelitian-penelitian Kelautan

dan Perikanan, (hlm 59-61), 8 November

2008. Universitas Brawijaya.

Subhan, B, Rahmawati, F., Arafat, D., Bayu, N.A.

2011a. Kondisi Kesehatan Karang

Fungiidae di Perairan Pulau Pramuka,

Kepulauan Seribu. Jurnal Teknologi

Perikanan dan Kelautan 2 (1) 2011:pp 41-50

Subhan, B., Arafat, D., Rahmawati, F., Hakim,

M.L., Soedharma, D. 2011b. Identifikasi

Penyakit Karang di Pulau Pramuka,

Kepulauan Seribu. (eds) DG. Bengen,
A.Sunuddin, CSU.Dewi. Prosiding Simposium Nasional Pengelolaan Pesisir, Laut, dan Pulau-pulau Kecil (hlm 20-25), 18 Nopember 2010. Himpunan Ahli Pengelolaan Pesisir Indonesia (HAPPI). Jakarta.

Soedharma, D., Arafat, D. 2006. Perkembangan Transplantasi Karang di Indonesia. Soedharma D, M. F. Rahardjo, Ferinaldy, Sri Eko Susilawati, Dondy Arafat (Ed). Prosiding Seminar Transplantasi. Bogor, 8 September 2005. Pusat Penelitian Lingkungan Hidup, Lembaga Penelitian dan Pengabdian Masyarakat. I PB.

Haris, A. 2011. Tranplantasi karang Acroporidea Pada Substrat Alami, Omni Akuatika X (12) 2011: pp33-42

Zamani, N.P., Subhan, B., Madduppa, H., Bachtiar, R., Destianto, M., Maulina T., 2009. Pengaruh Biorock terhadap Keragaman dan Kelimpahan Ikan Karang di Tanjung Lesung, Banten. Prosiding Simposium Nasional Terumbu Karang II. Program Rehabilitasi dan Pengelolaan Terumbu Karang CORMAP II. (hlm 158163), 19-20 November 2008. Direktorat Jenderal Kelautan dan Pulau-pulau Kecil Departemen Kelautan dan Perikanan. 